\title{
COVID-19 PANDEMIC STAY HOME PRACTICE: ITS EFFECT ON KÜTAHYA AIR QUALITY
}

\section{COVID-19 Pandemisi Evde Kal Uygulaması: Kütahya Hava Kalitesine Etkisi}

\author{
Muammer YILMAZ1
}

\begin{abstract}
In this study, it was aimed to investigate the effect of the applications of "stay home" and social movement restriction due to COVID-19 outbreak on air quality. In this descriptive cross-sectional study, measurement values of $\mathrm{PM}_{10}, \mathrm{PM}_{2.5}$ and $\mathrm{SO}_{2}$ variables in Kütahya province between 11th March and 25th May in 2019 and in 2020 were compared with 24-hour $\mathrm{PM}_{10}, \mathrm{PM}_{2.5}$ and $\mathrm{SO}_{2}$ mean limit values that are the air pollution criteria for Turkey and the World Health Organization (WHO). Between 11th March and 25th May in 2019, mean $\mathrm{PM}_{10}$ was $62.17 \pm 33.36 \mu \mathrm{g} / \mathrm{m}^{3}, \mathrm{mean} \mathrm{PM}_{2.5}$ was $11.34 \pm 10.43 \mu \mathrm{g} / \mathrm{m}^{3}$, mean $\mathrm{SO}_{2}$ was $18.18 \pm 13.98 \mu \mathrm{g} / \mathrm{m}^{3}$ and mean air temperature was $11.14 \pm 4.58^{\circ} \mathrm{C}$. Between 11th March and 25th May in 2020, mean PM10 was $42.25 \pm 26.20 \mu \mathrm{g} / \mathrm{m}^{3}$, mean $\mathrm{PM}_{2.5}$ was $16.69 \pm 8.77 \mu \mathrm{g} / \mathrm{m}^{3}$, mean $\mathrm{SO}_{2}$ was $6.93 \pm 5.36 \mu \mathrm{g} / \mathrm{m}^{3}$, mean air temperature was $13.27 \pm 6.00^{\circ} \mathrm{C}$. Compared to the same period of the previous year, there is a decrease in $\mathrm{PM}_{10}$ and $\mathrm{SO}_{2}$ concentrations in Kütahya province while an increase is observed in $\mathrm{PM}_{2.5}$ concentrations.

Keywords: COVID-19, stay home, air quality.
\end{abstract}

\section{Özet}

Bu çalışmada COVID-19 salgını nedeniyle "evde kal" ve toplumsal hareket kısıtlama uygulamasının hava kalitesine etkisinin incelenmesi amaçlanmıştır. Bu tanımlayıcı kesitsel araştırmada Kütahya il merkezinde 11 Mart-25 Mayıs 2019 ve 11 Mart-25 Mayıs 2020 tarihleri arasındaki $\mathrm{PM}_{10}, \mathrm{PM}_{2,5}$ ve $\mathrm{SO}_{2}$ değişkenlerine ait ölçüm değerleri Türkiye ve Dünya Sağlık Örgütü'nün (WHO) hava kirliliği kriteri olan $\mathrm{PM}_{10}, \mathrm{PM}_{2,5}$ ve $\mathrm{SO}_{2}$ değerlerinin 24 saatlik ortalama sınır değerleri

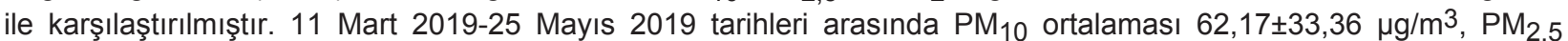
ortalaması $11,34 \pm 10,43 \mu \mathrm{g} / \mathrm{m}^{3}, \mathrm{SO}_{2}$ ortalaması $18,18 \pm 13,98 \mu \mathrm{g} / \mathrm{m}^{3}$, hava sıcaklığı ortalaması $11.14 \pm 4.58^{\circ} \mathrm{C}^{\prime}$ dir. 11 Mart 2020-25 Mayıs 2020 tarihleri arasında $\mathrm{PM}_{10}$ ortalaması 42,25 $\pm 26,20 \mu \mathrm{g} / \mathrm{m}^{3}, \mathrm{PM}_{2,5}$ ortalaması 16,69 $\pm 8,77 \mu \mathrm{g} / \mathrm{m}^{3}$, $\mathrm{SO}_{2}$ ortalaması $6,93 \pm 5,36 \mu \mathrm{g} / \mathrm{m}^{3}$, hava sıcaklığı ortalaması $13,27 \pm 6,00^{\circ} \mathrm{C}$ 'dır. Kütahya'da önceki yıl aynı dönem ile karşılaştırıldığında $\mathrm{PM}_{10}$ ve $\mathrm{SO}_{2}$ konsantrasyonlarında azalma olduğu görülürken $\mathrm{PM}_{2,5}$ konsantrasyonlarında artış görülmektedir.

Anahtar kelimeler: COVID-19, evde kal, hava kalitesi.

1- Kütahya Sağlık Bilimleri Üniversitesi Tıp Fakültesi Halk Sağlığı Ana Bilim Dalı, Kütahya, Türkiye

Sorumlu Yazar / Corresponding Author: Dr. Öğr. Üyesi Muammer Yılmaz e-posta / e-mail: zerkesa@gmail.com

Geliş Tarihi / Received: 25.09.2020, Kabul Tarihi / Accepted: 09.03.2020

ORCID: Muammer YILMAZ: 0000-0002-8728-7635

Nasıl Atıf Yaparım / How to Cite: Yılmaz A. COVID-19 pandemic stay home practice: its effect on Kütahya air quality. ESTUDAM Public Health Journal. 2021;6(2):123-9. 


\section{Introduction}

Air pollution is an important public health problem. Each year, 3.7 million deaths are attributed to outdoor air pollution. In addition, about 7 million premature deaths were reported by the World Health Organization (WHO) due to air pollution in 2012. Studies show a relationship between air pollution and respiratory system diseases, ischemic heart diseases, stroke and cancers (1). Air pollution is determined by the amount of such substances in the air as ozone $\left(\mathrm{O}_{3}\right)$, carbon monoxide (CO), sulphur dioxide $\left(\mathrm{SO}_{2}\right)$, nitrogen oxide $\left(\mathrm{NO}_{2}\right)$, liquid and particles. Urban air pollution in Turkey is typically determined by measuring sulphur dioxide $\left(\mathrm{SO}_{2}\right)$ and particulate matter $10\left(\mathrm{PM}_{10}\right)$ in the atmosphere (2). Particulate matter (PM) occurs as a result of combustion of solid fuels such as petroleum products, coal and biomass used in vehicles, household and industry, and industrial activities such as construction, mining, and cement production $(3,4,5)$. In 2013, PM was classified as a cause of lung cancer by the WHO International Agency for Cancer on Research (IARC) (3).

Sulphur dioxide is mainly formed by the burning of fossil fuels such as coal and petroleum. Exposure to $\mathrm{SO}_{2}$ can worsen respiratory diseases such as asthma and chronic bronchitis, and also increase ER admissions and hospitalizations $(3,4,5)$.
With the occurrence of severe unexplained pneumonia cases affecting the respiratory tract in Wuhan city of China in 2019, the Chinese Center for Disease Control and Prevention went into an emergency alarm. WHO named the new type 2019-nCoV virus as COVID-19 $(6,7)$. It was determined that COVID-19 has a similar structure with SARS-CoV and MERS-CoV, which are members of the coronavirus family, but it is faster than others in terms of spread rate and infectious properties (6). The first coronavirus case in Turkey was identified on March 11th, 2020. In order to reduce the pace of the epidemic, formal education was terminated at all educational institutions on March 16th, 2020. Many measures have been implemented such as flexible working with minimum staff in public institutions, termination of public transportation, closure of eating, drinking and entertainment places, and the curfew for those 65 years old and over. On March 25th, 2020 " Stay Home Turkey " application began $(8,9)$.

The period of inactivity, which started with the social movement restriction imposed due to the COVID-19 pandemic, reduced traffic density and industrial production processes. In this study, it was aimed to determine how air pollution changed during the COVID-19 pandemic in Kütahya compared to the previous year, based on $\mathrm{PM}_{10}, \mathrm{PM}_{2.5}$ and $\mathrm{SO}_{2}$ levels.

\section{Material and Method}

\section{The data of this descriptive cross-sectional study are hourly} measurement values of $\mathrm{PM}_{10}, \mathrm{PM}_{2.5}$ and $\mathrm{SO}_{2}$ variables taken from www.havaizleme. gov.tr website belonging to Ministry of Environment and Urbanization between 11th March and 25th May of 2019 and of 2020. There is an air quality measurement station in the Kütahya province (10). Since the pollutants are measured hourly at the stations, daily average measurement values for each pollutant were calculated by taking the average of the measurements of the days for which at least $75 \%$ measurements) of the daily-required 24 measurements were made. The values obtained by were compared with $\mathrm{PM}_{10}$, $\mathrm{PM}_{2.5}$ and $\mathrm{SO}_{2}$ 24-hour average limit values, which are the air pollution criteria of Turkey and $\mathrm{WHO}$. The population of Kütahya province was 272,367 in total in 2016 according to the data of Turkish Statistical Institute (TSI) (11). Ethics committee approval was not obtained for the study in accordance with the "Regulation on Clinical Researches" dated August 19th, 2011 and numbered 28030 (12). 
Statistical analysis

SPSS Statistics v22.0 was used in the study. Mean, standard deviation and standard error values of the data were calculated. Student $t$ test was used to compare the means of $\mathrm{PM}_{10}, \mathrm{PM}_{2.5}$ and $\mathrm{SO}_{2}$ values. Chi-square test was used to compare categorical variables and statistical significance level was taken as $p<0.05$.

\section{Results}

When the daily average measurement values were calculated by taking the average of the hourly measurements of the days for which at least $75 \%$ (18 measurements) of the dailyrequired 24 measurements were made for each pollutant at the stations, the number of days with quality data was for $\mathrm{PM}_{10} 66$ $(86.8 \%)$ in 2019 and $68(89.4 \%)$ in 2020 , for $\mathrm{PM}_{2.5} 75(98.6 \%)$ in 2009 and 71 (93.4\%) in 2020, for $\mathrm{SO}_{2} 22(28.9 \%)$ in 2019 and 71 $(93.4 \%)$ in 2020 .

Table 1: The change in $\mathrm{PM}_{10}, \mathrm{PM}_{2.5}, \mathrm{SO}_{2}$, and air temperature averages in Kütahya Province by years.

\begin{tabular}{|c|c|c|c|c|c|c|}
\hline Parameters & Year & $\mathbf{N}$ & Mean & Std. Deviation & Std. Error Mean & $t ; p$ \\
\hline \multirow{2}{*}{$P M_{10}\left(\mu g / m^{3}\right)$} & 2019 & 66 & 62.17 & 33.36 & 4.10 & \multirow{2}{*}{$3.837 ;<0.001$} \\
\hline & 2020 & 68 & 42.25 & 26.20 & 3.17 & \\
\hline \multirow{2}{*}{$\mathrm{PM}_{2.5}\left(\mu \mathrm{g} / \mathrm{m}^{3}\right)$} & 2019 & 75 & 11.34 & 10.43 & 1.20 & \multirow{2}{*}{$-3.345 ; 0.001$} \\
\hline & 2020 & 71 & 16.69 & 8.77 & 1.04 & \\
\hline \multirow{2}{*}{$\mathrm{SO}_{2}\left(\mu \mathrm{g} / \mathrm{m}^{3}\right)$} & 2019 & 22 & 18.18 & 13.98 & 2.98 & \multirow[b]{2}{*}{$3.690 ; 0.001$} \\
\hline & 2020 & 71 & 6.93 & 5.36 & 0.63 & \\
\hline \multirow{2}{*}{ Air temperature $\left({ }^{\circ} \mathrm{C}\right)$} & 2019 & 43 & 11.14 & 4.58 & 0.69 & \multirow{2}{*}{$-2.016 ; 0.046$} \\
\hline & 2020 & 74 & 13.27 & 6.00 & 0.69 & \\
\hline
\end{tabular}

Table 2: The change in $\mathrm{PM}_{10}, \mathrm{PM}_{2.5}, \mathrm{SO}_{2}$, and air temperature averages in Kütahya Province by months and years.

\begin{tabular}{|c|c|c|c|c|c|c|}
\hline Parameters & Month & $\mathbf{n}$ & Mean & Std. Deviation & $\begin{array}{c}\text { Std. Error } \\
\text { Mean }\end{array}$ & $t ; p$ \\
\hline \multirow{2}{*}{$\mathrm{PM}_{10}\left(\mu \mathrm{g} / \mathrm{m}^{3}\right)$} & March19 & 15 & 70.50 & 36.82 & 9.50 & \multirow{2}{*}{$1.424 ; 0.163$} \\
\hline & March20 & 21 & 55.89 & 24.82 & 5.41 & \\
\hline \multirow{2}{*}{$\mathrm{PM}_{2.5}\left(\mu \mathrm{g} / \mathrm{m}^{3}\right)$} & March19 & 21 & 12.21 & 13.69 & 2.98 & \multirow{2}{*}{$-2.422 ; 0.020$} \\
\hline & March20 & 20 & 21.87 & 11.69 & 2.61 & \\
\hline \multirow{2}{*}{$\mathrm{SO}_{2}\left(\mathrm{ug} / \mathrm{m}^{3}\right)$} & March19 & 9 & 30.41 & 11.60 & 3.86 & \multirow{2}{*}{$4.143 ; \mathbf{0 . 0 0 2}$} \\
\hline & March20 & 19 & 13.15 & 6.77 & 1.55 & \\
\hline \multirow{2}{*}{ Air temperature $\left({ }^{\circ} \mathrm{C}\right)$} & March19 & 0 & 0 & 0 & 0 & \multirow{2}{*}{ - } \\
\hline & March20 & 21 & 8.39 & 4.27 & 0.93 & \\
\hline \multirow{2}{*}{$\mathrm{PM}_{10}\left(\mu \mathrm{g} / \mathrm{m}^{3}\right)$} & April19 & 26 & 70.52 & 35.11 & 6.88 & \multirow{2}{*}{$3.950 ;<0.001$} \\
\hline & April20 & 29 & 36.76 & 28.18 & 5.23 & \\
\hline \multirow{2}{*}{$\mathrm{PM}_{2.5}\left(\mu \mathrm{g} / \mathrm{m}^{3}\right)$} & April19 & 29 & 13.84 & 10.22 & 1.89 & \multirow{2}{*}{$-1.653 ; 0.105$} \\
\hline & April20 & 29 & 17.55 & 6.43 & 1.19 & \\
\hline \multirow{2}{*}{$\mathrm{SO}_{2}\left(\mu \mathrm{g} / \mathrm{m}^{3}\right)$} & April19 & 5 & 16.70 & 8.96 & 4.01 & \multirow{2}{*}{$2.959 ; \mathbf{0 . 0 4 1}$} \\
\hline & April20 & 29 & 4.78 & 2.07 & 0.38 & \\
\hline \multirow{2}{*}{ Air temperature $\left({ }^{\circ} \mathrm{C}\right)$} & April19 & 18 & 7.84 & 3.97 & 0.93 & \multirow{2}{*}{$-4.567 ;<0.001$} \\
\hline & April20 & 30 & 12.42 & 2.94 & 0.53 & \\
\hline \multirow{2}{*}{$\mathrm{PM}_{10}\left(\mu \mathrm{g} / \mathrm{m}^{3}\right)$} & May19 & 25 & 48.49 & 24.99 & 4.99 & \multirow{2}{*}{$1.916 ; 0.062$} \\
\hline & May20 & 18 & 35.17 & 18.38 & 4.33 & \\
\hline \multirow{2}{*}{$\mathrm{PM}_{2.5}\left(\mu \mathrm{g} / \mathrm{m}^{3}\right)$} & May19 & 25 & 7.69 & 5.94 & 1.18 & \multirow{2}{*}{$-2.113 ; 0.040$} \\
\hline & May20 & 22 & 10.84 & 3.91 & 0.83 & \\
\hline \multirow{2}{*}{$\mathrm{SO}_{2}\left(\mu \mathrm{g} / \mathrm{m}^{3}\right)$} & May19 & 8 & 5.34 & 2.10 & 0.74 & \multirow{2}{*}{$1.154 ; 0.258$} \\
\hline & May20 & 23 & 4.49 & 1.67 & 0.34 & \\
\hline \multirow{2}{*}{ Air temperature $\left({ }^{\circ} \mathrm{C}\right)$} & May19 & 25 & 13.51 & 3.40 & 0.68 & \multirow{2}{*}{$-3.785 ; 0.001$} \\
\hline & May20 & 23 & 18.85 & 5.92 & 1.23 & \\
\hline
\end{tabular}


Between 11th March 2019 and 25th May 2019, mean $\mathrm{PM}_{10}$ was $62.17 \pm 33.36$ $\mu \mathrm{g} / \mathrm{m}^{3}$, mean $\mathrm{PM}_{2.5}$ was $11.34 \pm 10.43$, mean $\mathrm{SO}_{2}$ was $18.18 \pm 13.98$ and mean air temperature was $11.14 \pm 4.58$. Between 11th March 2020 and 25th May 2020, mean PM 10 was $42.25 \pm 26.20 \mu \mathrm{g} / \mathrm{m}^{3}$, mean $\mathrm{PM}_{2.5}$ was $16.69 \pm 8.77$, mean $\mathrm{SO}_{2}$ was $6.93 \pm 5.36$ $\mu \mathrm{g} / \mathrm{m}^{3}$, and mean air temperature was $13.27 \pm 6.00^{\circ} \mathrm{C}$ (Table 1 ). When compared by months, while $\mathrm{PM}_{2.5}$ values increased in March, April and May, $\mathrm{PM}_{10}$ and $\mathrm{SO}_{2}$ values decreased in March, April and May (Table 2).

When the days the PM10 values exceeded the WHO limit values $\left(50 \mu \mathrm{g} / \mathrm{m}^{3}\right)$ during the pandemic process and in the previous year were compared, no statistical difference was seen between March, April and May (Figure 1). A statistical difference was found in March when the days the $\mathrm{SO}_{2}$ values exceeded the WHO limit values (20 $\mu \mathrm{g} / \mathrm{m}^{3}$ ) during the pandemic process and in the previous year were compared $(p=0.003)$ There was no statistical difference in April. In May, WHO limit values of $\mathrm{SO}_{2}$ values (20 $\mu \mathrm{g} / \mathrm{m}^{3}$ ) were never exceeded (Figure 2).

When the days the $\mathrm{PM}_{2.5}$ values exceeded the WHO limit values $\left(25 \mu \mathrm{g} / \mathrm{m}^{3}\right)$ during the pandemic process and in the previous year were compared, no statistical difference was found between March, April and May (Figure 3).

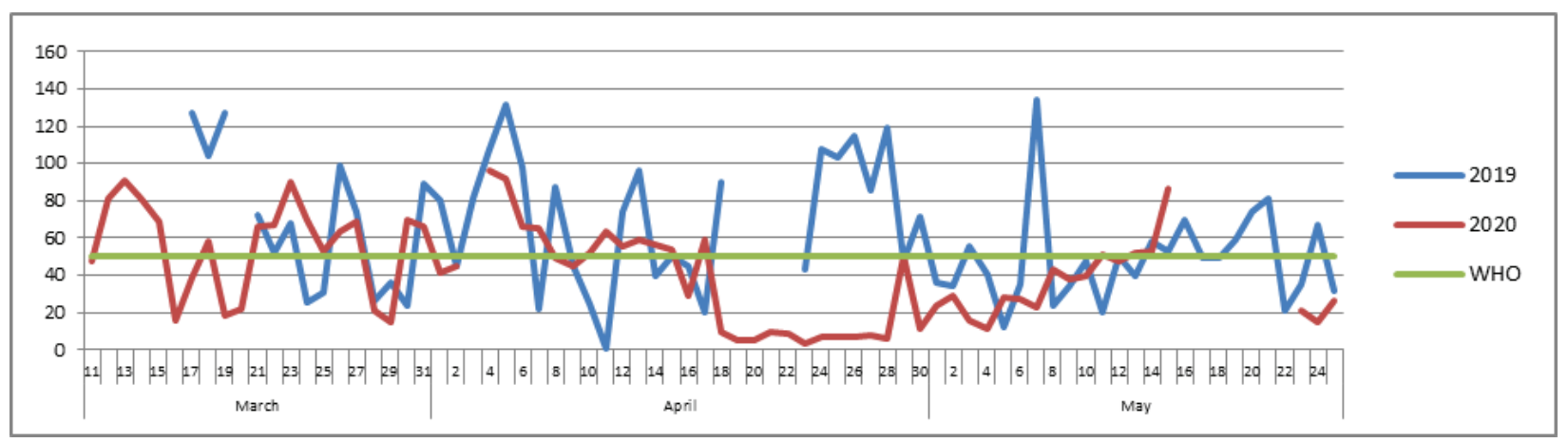

Figure 1: The change in $\mathrm{PM}_{10}\left(\mu \mathrm{g} / \mathrm{m}^{3}\right)$ means in Kütahya Province by years WHO limit value $\left(50 \mu \mathrm{g} / \mathrm{m}^{3}\right)$.

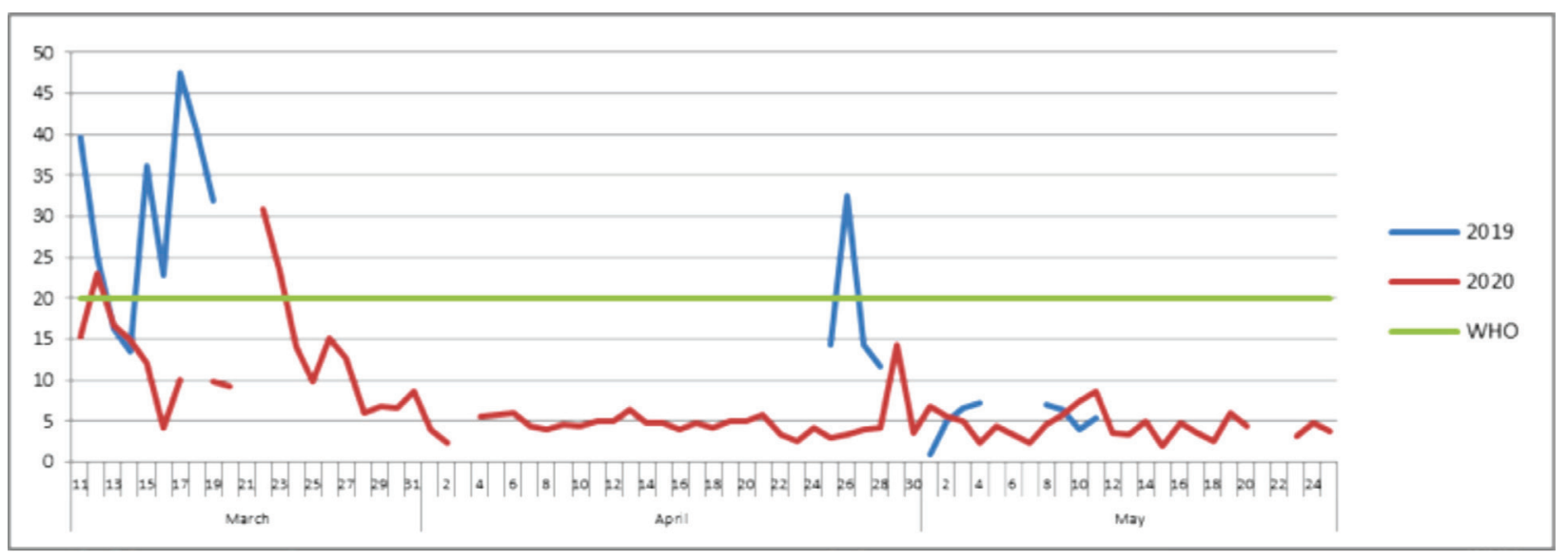

Figure 2: The change in $\mathrm{SO}_{2}\left(\mu \mathrm{g} / \mathrm{m}^{3}\right)$ means in Kütahya Province by years WHO limit value $\left(20 \mu \mathrm{g} / \mathrm{m}^{3}\right)$. 


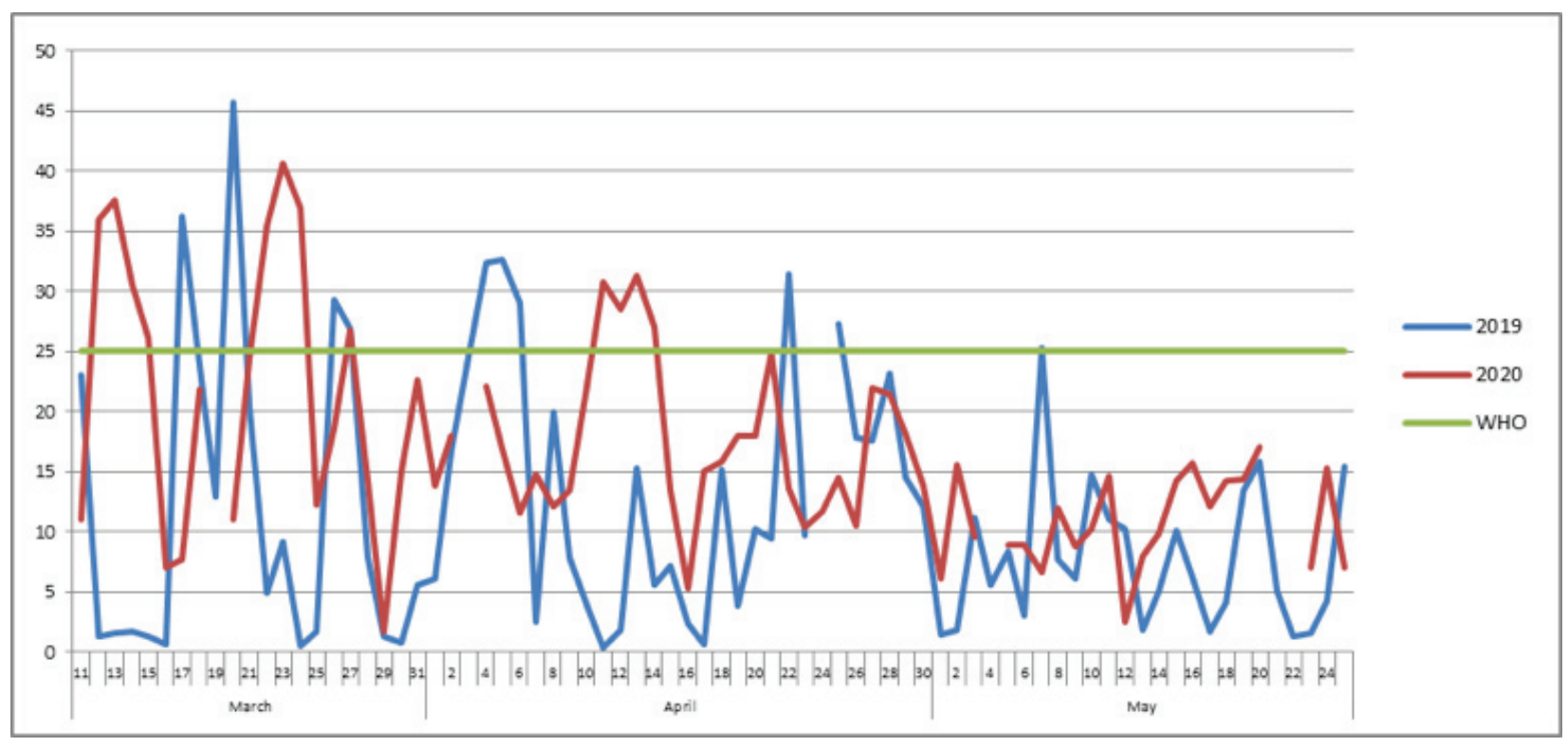

Figure 3: The change in $\mathrm{PM}_{2.5}\left(\mu \mathrm{g} / \mathrm{m}^{3}\right)$ means in Kütahya province by years WHO limit $\left(25 \mu \mathrm{g} / \mathrm{m}^{3}\right)$.

\section{Discussion}

To stop the spread of COVID-19, a number of rapid and strict counter-measures were taken by many countries around the world, including limiting the mobility of the population in cities and banning almost all preventable activities. As a result of these measures, a decrease was seen in economic activities and road traffic. In Kütahya, measures to restrict population and economic activities have been implemented to stop the spread of COVID-19. In Kütahya, while restriction was applied mostly in traffic and at workplaces that perform small-scale manufacturing, large-scale industrial facilities continued their activities. This study was conducted to evaluate how these applications affected air pollution concentrations.

Compared to the same period of the previous year, there is a decrease in $\mathrm{PM}_{10}$ and $\mathrm{SO}_{2}$ concentrations in Kütahya, while an increase in $\mathrm{PM}_{2.5}$ concentrations is observed. As a result of the measures, a decrease in $\mathrm{PM}_{2.5}$ concentrations is expected, but there is no consistent decrease in cities in Europe yet (13). This can be explained by that the main sources of this pollutant are more diverse in European countries, including fuel used for industrial activities, road traffic and heating residential, commercial and public buildings and also that a significant part of the particulate matter is formed in the atmosphere through reactions of other air pollutants containing ammonia (13). However, data from the European Environment Agency show that there are nearly half reductions in air pollutant concentrations due to reduced traffic and other activities in some major cities thanks to the measures taken (14). The results obtained in a study in Morocco showed that the difference between the concentrations recorded before and during the lockdown period was $75 \%, 49 \%$ and $96 \%$ for $\mathrm{PM}_{10}, \mathrm{SO}_{2}$ and $\mathrm{NO}_{2}$, respectively (15). Like weather conditions, other factors will also contribute to changes observed in air pollution. Compared with the same period of the previous year in Kütahya, the air temperature was measured higher. Changes in meteorology can cause air pollution to increase or decrease. When the relationship between changes in emissions and changes in concentrations and meteorological changes combined, why lower air pollution does not occur in all regions can be explained (13). Residential heating, which has a significant share in pollution in Kütahya, may have had little effect due to the higher air temperature compared to the 
previous year. The main air pollutants in a city can be determined by stopping production of large manufacturing industry, small manufacturing industry, and residential heating by turns for a while.

Air quality monitoring stations must provide data at $75 \%$ rate at least (16). However, it was found that the measurements in the station in Kütahya were

\section{Conclusions}

It is seen that there is a partial improvement in air quality in Kütahya during the pandemic period. When air pollutant concentrations are compared to the same period of the previous year, a decrease is observed in $\mathrm{PM}_{10}$ and $\mathrm{SO}_{2}$ concentrations, while there is an increase in $\mathrm{PM}_{2.5}$ concentrations. The decrease in $\mathrm{PM}_{10}$ and $\mathrm{SO}_{2}$ concentrations may have occurred due to the increase in temperature compared to the previous year and restrictions. The fact that large-scale industries located close to insufficient. Especially in 2019, $\mathrm{SO}_{2}$ measurements remained at $28.9 \%$. The first thing to do in the solution of a problem affecting public health is to be able to define the current situation correctly. For this purpose, the measurements made at Kütahya Air Quality Monitoring Station should be done regularly and adequately

the center are outside the restrictions and intercity traffic may have negatively affected $\mathrm{PM}_{2.5}$ concentrations. Meteorological parameters affecting air quality such as pressure and humidity should also be evaluated in studies. In addition, in order to determine the main air polluting sources in the city, detailed analyzes can be made by interrupting the large manufacturing industry production, small manufacturing industry production and residential heating respectively. 


\section{References}

1. World Health Assembly, 69. Sixty-ninth World Health Assembly, Geneva, 23-28 May 2016: resolutions and decisions, annexes. Available from: https://apps. who.int/iris/handle/10665/259134

2. Bayram H, Dörtbudak, Z, Fişekçi F E, Kargın M, Bülbül B. Following the Panel "Effects of air pollution on human health, the problem of air pollution in the world, in our country and in our region". Medical Journal. 2006;33:105-12.

3. World Health Organization (WHO). Air pollution. [cited 2020 Jun 4] Available from: http://www.who.int/airpollution/ ambient/pollutants/en/

4. Tecer LH. Air pollution and our health. Education in the Light of Science and Mind. 2011;135:15-29.

5. WHO Media center. 7 million premature deaths annually linked to air pollution. [cited 2020 Jun 4] Available from: http://www.who.int/mediacentre/news/rel eases/2014/air-pollution/en/

6. Team. TNCPERE. The epidemiological characteristics of an outbreak of 2019 novel coronavirus diseases (COVID-19) - China, 2020. China CDC Wkly [Internet]. 2020 [cited 2020 Jun 4];2(8):113-22. Available from: http://weekly.chinacdc.cn/en/article/id/e5 3946e2-c6c4-41e9-9a9b-fea8db1a8f51

7. WHO. Novel Coronavirus-China. [Internet]. 2020 [cited 2020 Jun 4] Available from: https://www.who.int/csr/ don/12-january-2020-novel-coronaviruschina/en/

8. T.R. Ministry of Health, COVID-19 new coronavirus disease. [cited 2020 Jun 4] Available from: https://covid19bilgi. saglik.gov.tr/tr/gunluk-vaka.html
9. T.R. Presidency [Internet]. [cited 2020 Jun 4] Available from: https://www.tccb. gov.tr/haberler/410/118051/-her-vatanda simizin-cani-bizim-icin-ayni-derecede-de gerlidir-bunun-icin-evde-kal-turkiye-diyor uz-

10. Ministry of Environment and Urbanization, National Air Quality Monitoring Network. [cited 2020 May 26] Available from: http://index.havaizleme. gov.tr/Report/Station

11. Turkish Statistical Institute, General Population Censuses. Available from: http://tuik.gov.tr/PreTablo.do?alt_id=104 7

12. Regulation on Clinical Researches. [cited 2020 Jun 4] Available from: http://www.resmigazete.gov.tr/eskiler/20 11/08/20110819-9.htm

13. European Environment Agency. [cited 2020 Jun 4] Available from: https://www.eea.europa.eu/themes/air/ai $r$-quality-and-covid19

14. European Environment Agency. [cited 2020 Jun 4] Available from: https://www.eea.europa.eu/highlights/air -pollution-goes-down-as

15. Otmani A, Benchrif A, Tahri M, Bounakhla M, Chakir EM, El Mahjoub; El Bouch M, Krombi M. Impact of COVID-19 lockdown on PM10, SO2 and NO2 concentrations in Salé City (Morocco). Sci Total Environ; 2020 [cited 2020 May 19];735(139541):1-5. doi:10.1016/j. scitotenv. 2020.139541

16. T.C. Cumhurbaşkanlığı Mevzuat Bilgi Sistemi. Air Quality Assessment and Management Regulation [Internet] [cited 2020 Jun 4] Available from: http://www.mevzuat.gov.tr/Metin.Aspx?M evzuatKod=7.5.12188\&Mevzuat Iliski $=0$ 